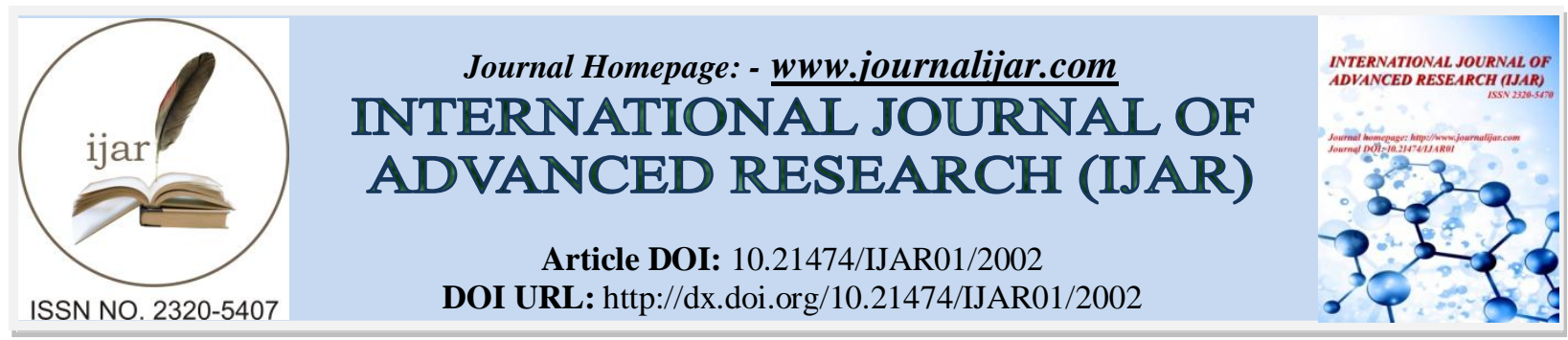

RESEARCH ARTICLE

\title{
CYTOGENETIC AND IMMUNOLOGIC STUDIES ON COUPLE EXPERIENCING BAD OBSTETRIC HISTORY
}

\author{
Sumitha Prabhu PS ${ }^{1}$, Swapna C Senan ${ }^{1}$, Viji Krishnan ${ }^{2}$, Sini Joy ${ }^{3}$ and Dinesh Roy D ${ }^{3}$. \\ 1. Research Scholar, Meenakshi University, West KK Nagar, Chennai- 600078 . TN, India. \\ 2. Department of Biochemistry, Jubilee Mission Medical College and Research Institute, Thrissur, Kerala, India. \\ 3. Genetika, Centre for Advanced Genetic Studies, Pettah P O, Thiruvananthapuram -695024, Kerala, India.
}

\section{Manuscript Info}

\section{Manuscript History}

Received: 12 August 2016

Final Accepted: 22 September 2016

Published: November 2016

Key words:-

Bad obstetric history, Chromosome abnormality, Karyotyping

\section{Abstract}

Bad obstetric history (BOH) is the common complication of pregnancy, affecting approximately $15 \%$ of all clinically recognized pregnancies in the general population. Majority of sporadic cases before 10 week of gestation are as a result of chromosomal anomalies. The overall frequency of $\mathrm{BOH}$ was estimated from $1 \%$ to $3 \%$. $\mathrm{BOH}$ also referred as Recurrent pregnancy loss (RPL) or Recurrent miscarriages (RM) or Habitual abortion, because these are historically defined as 3 consecutive pregnancy losses prior to 20 weeks from the last menstrual period. Incidence of $\mathrm{BOH}$ was found to be $5.27 \%$, including $(1.4 \%)$ with history of unexplained stillbirth or neonatal loss. The causes of $\mathrm{BOH}$ may be genetic, hormonal, abnormal maternal immune response, and maternal infection. The present study was carried out in 30 couples suffering with bad obstetric history were selected as study subject. The cytogenetic analysis results were correlated with various demographic, clinical and lifestyle aspects of couples with $\mathrm{BOH}$. Increasing maternal age, paternal age, duration of married life, number of gestations, number of abortions, infections and history of illness etc. can lead to chromosome abnormality. Identify any recurrent or non-recurrent causes of pregnancy loss and put in place a management plan to reduce or modify the risks in the current or future pregnancies.

Copy Right, IJAR, 2016,. All rights reserved.

\section{Introduction:-}

Bad Obstetric History (BOH) implies previous unfavorable fetal outcome in terms of two or more consecutive spontaneous abortion, history of intrauterine fetal death, intrauterine growth retardation, still births, early neonatal death and/or congenital anomalies (Kumari et al., 2011). BOH has been studied with different standardizations for various parameters like epidemiology, etiology and management. It is well realized that at least $12-15 \%$ of all recognized conceptions end in miscarriage, and pre-clinical pregnancy loss rate is still higher (Paul, 1994). One to two percent of couples experience three or more consecutive losses (Meka et al., 2006).

The causes of $\mathrm{BOH}$ may be genetic, hormonal, abnormal maternal immune response, maternal infection and anatomical (Nickerson et al., 2012). However, an increasing risk of fetal loss with increasing maternal age has been documented in women aged more than 30 years (Andersen et al., 2000). Primary infection caused by TORCH 
(Toxoplasma Gondi, Rubella virus, Cytomegalo virus, and Herpes simplex virus) are the main cause of BOH (AlHilli et al., 2014). Gestational diabetes mellitus (GDM) forms the most common medical complication of pregnancy (Ambroise et al., 2000).

In couples with $\mathrm{BOH}$ percentages of chromosomal abnormality (CA) vary from 1 to $25 \%$ for individuals or to $50 \%$ for couples. Most frequently occurring CA is balanced chromosomal rearrangement, i.e. translocation; other CAs seen usually are sex chromosomal mosaicism, inversions and ring chromosomes. Additional structural abnormalities associated with recurrent pregnancy loss (RPL) include chromosomal inversions and insertions. Reciprocal translocations are found to be $60 \%$ and Robertsonian translocation $40 \%$ in couples experiencing RPL. Approximately $2 \%$ to $4 \%$ of RPL is associated with a parental balanced structural chromosome rearrangement. Single gene defects, such as those associated with cystic fibrosis or sickle cell anemia, are seldom associated with RPL (Simpson and Elias, 2003). The most prevalent abnormality of spontaneous abortion is chromosomal aneuploidy (JiHyae Lim, 2013). Balanced structure chromosome abnormalities in parents can cause bad obstetric history. In couples with two or more miscarriage the incidence of these abnormalities varies between 3 to $6 \%$ (Franssen et al., 2005).

The immune factors associated with pregnancy loss are classified as autoimmune and alloimmune factors. The autoimmune factors include the synthesis of autoantibodies (anti-phospholipid antibodies, anti nuclear antibodies and anti thyroid antibodies) (Sutandar et al., 2007). The viscosity of blood slightly increases during pregnancy, but in some women the blood is found to clot more easily due to the presence of certain antibodies called antiphospholipid antibodies. These blood clots in the placental blood vessels may decrease the blood flow to the baby resulting in miscarriage (Nadia and Hadi, 2014).

The identification of chromosomal abnormality as the etiology has facilitated the counseling and appropriate management (Boonruang et al., 2005). Genetic testing of fetuses provides information about potential birth defects and gives couples high level of probability information upon which to base decisions. So far, many studies have been conducted to evaluate the role of cytogenetic and immunologic studies on couple experiencing bad obstetric history. No systematic studies were conducted to evaluate the cytogenetics correlate it with immunology and that causes $\mathrm{BOH}$. Hence the present study was undertaken to aware the people about the cytogenetic and immunologic studies on couple experiencing bad obstetric history.

\section{Materials and Methods:-}

Thirty couples suffering with bad obstetric history were selected as study subjects for this study. Detailed demographic, clinical and lifestyle characteristics were recorded using proforma. These couples were referred from various infertility clinics and maternity centers of Kerala to Genetika, Centre for Advanced Genetic Studies, Trivandrum, Kerala.

The fresh blood was collected by venepuncture and transferred into vacuutainer containing sodium heparin as anticoagulant. Added 5 to 6 drops of whole blood samples to a vial containing 10ml of RPMI 1640 medium supplemented with $15 \%$ foetal bovine serum. Then phytohaemagglutinin (PHA, 100 $\mu \mathrm{g} / \mathrm{ml}$ ) was added to proliferate the lymphocyte cells and incubated at $37^{\circ} \mathrm{C}$ for $72 \mathrm{hrs}$. At the $70^{\text {th }}$ hour to the culture added a drop of colchicine $(0.04 \mu \mathrm{g} / \mathrm{ml})$ to arrest the cell division at metaphase, then mixed gently and kept in incubator at $37^{0} \mathrm{C}$ for 2 hours. After incubation they were treated with a hypotonic solution $(0.075 \mathrm{M} \mathrm{KCl})$ for 1 min and fixed in fresh fixative solution (methanol: acetic acid, 3:1). The cells were dropped onto slides and the slides were air dried and stained with $10 \%$ Giemsa. Washed the slides in distilled water and observed under a research microscope through $100 \mathrm{x}$ objective. For karyotyping and detecting the structural anomalies, GTG banding technique was performed. To detect numerical and structural abnormalities 20-25 metaphases were analyzed and 5-6 metaphases were karyotyped. 
Result:-

Table 1:- Distribution of couples karyotype according to demographic characteristics.

\begin{tabular}{|c|c|c|c|c|}
\hline Category & Variable & $\begin{array}{c}\text { Number } \\
\text { (Percentage) }\end{array}$ & $\begin{array}{c}\text { Normal } \\
\text { Karyotype } \\
\text { (Percentage) }\end{array}$ & $\begin{array}{c}\text { Abnormal } \\
\text { Karyotype } \\
\text { (Percentage) }\end{array}$ \\
\hline Paternal age (years) & $25-35$ & $14(46.7 \%)$ & $12(85.8 \%)$ & $2(14.2 \%)$ \\
\cline { 2 - 5 } & $36-47$ & $16(53.3 \%)$ & $6(37.5 \%)$ & $10(62.5 \%)$ \\
\hline \multirow{2}{*}{$\begin{array}{c}\text { Maternal age } \\
\text { (years) }\end{array}$} & $24-34$ & $27(90 \%)$ & $20(74.1 \%)$ & $7(25.9 \%)$ \\
\cline { 2 - 5 } $\begin{array}{c}\text { Duration of married } \\
\text { life of couples } \\
\text { (years) }\end{array}$ & $35-44$ & $3(10 \%)$ & $1(33.3 \%)$ & $2(66.7 \%)$ \\
\cline { 2 - 5 } & 1 to 4 & $13(43.3 \%)$ & $8(61.6 \%)$ & $5(38.4 \%)$ \\
\cline { 2 - 5 } & 9 to 8 & $9(30 \%)$ & $4(44.4 \%)$ & $5(55.6 \%)$ \\
\cline { 2 - 5 } & 13 to 12 & $5(16.7 \%)$ & $1(20 \%)$ & $4(80 \%)$ \\
\hline
\end{tabular}

The distribution of couples karyotype according to demographic characteristics of study subjects were showed in (Table 1). The paternal age of the study subject was observed and 36 to 47 years of age were showed $37.5 \%$ of normal karyotype and $62.5 \%$ of abnormal karyotype. Maternal age of the study subject was observed and 35-44 years of age were showed $33.3 \%$ of normal karyotype and $66.7 \%$ of abnormal karyotype. Duration of married life of the couples were observed and among them those had duration of 13-17 years of married life showed 33.3\% normal karyotype and $66.7 \%$ were abnormal karyotype.

Table 2:- Distribution of maternal karyotype according to clinical characteristics.

\begin{tabular}{|c|c|c|c|c|}
\hline Category & Variable & $\begin{array}{c}\text { Number } \\
\text { (Percentage) }\end{array}$ & $\begin{array}{c}\text { Normal } \\
\text { Karyotype } \\
\text { (Percentage) }\end{array}$ & $\begin{array}{c}\text { Abnormal } \\
\text { Karyotype } \\
\text { (Percentage) }\end{array}$ \\
\hline $\begin{array}{c}\text { Number of gestation } \\
\text { (n) }\end{array}$ & 1 to 3 & $15(50 \%)$ & $14(93.3 \%)$ & $1(6.7 \%)$ \\
\cline { 2 - 5 } $\begin{array}{c}\text { Number of abortion } \\
(\mathrm{n})\end{array}$ & 4 to 7 & $15(50 \%)$ & $5(33.3 \%)$ & $6(66.7 \%)$ \\
\cline { 2 - 5 } & $<2$ & $16(53.3 \%)$ & $15(93.7 \%)$ & $1(6.3 \%)$ \\
\cline { 2 - 5 } & 5 to 4 & $3(10 \%)$ & $1(33.3 \%)$ & $2(66.7 \%)$ \\
\hline \multirow{2}{*}{$\begin{array}{c}\text { Number of } \\
\text { MTPs (n) }\end{array}$} & 2 to 6 & $11(36.7 \%)$ & $2(18.1 \%)$ & $9(81.9 \%)$ \\
\cline { 2 - 5 } & 2 to 3 & $3(10 \%)$ & $23(85.1 \%)$ & $4(14.9 \%)$ \\
\hline
\end{tabular}

The distribution of maternal karyotype according to clinical characteristics was showed in Table 2. The number of gestations of the mother was observed and those with number of gestation 4 to 7 times showed $33.3 \%$ normal karyotype and $66.7 \%$ abnormal karyotype. Moreover the study subjects suffering with 5 to 6 times abortions were showed normal karyotype of $18.1 \%$ and increased incidence $(81.9 \%)$ of abnormal karyotype. In short, the study subject with 2 to 3 times of medical terminations of pregnancies (MTP) was showed high abnormal karyotype $(66.7 \%)$.

Table 3:- Distribution of maternal karyotype according to lifestyle characteristics.

\begin{tabular}{|c|c|c|c|c|}
\hline Category & Variable & $\begin{array}{c}\text { Number } \\
\text { (Percentage) }\end{array}$ & $\begin{array}{c}\text { Normal } \\
\text { Karyotype } \\
\text { (Percentage) }\end{array}$ & $\begin{array}{c}\text { Abnormal } \\
\text { Karyotype } \\
\text { (Percentage) }\end{array}$ \\
\hline Clinical condition & No & $14(46.7 \%)$ & $12(85.8 \%)$ & $2(14.2 \%)$ \\
\hline & Yes & $16(53.3 \%)$ & $6(37.5 \%)$ & $10(62.5 \%)$ \\
\hline \multirow{2}{*}{ History of illness } & No & $18(60 \%)$ & $15(83.3 \%)$ & $3(16.7 \%)$ \\
\cline { 2 - 5 } & Yes & $12(40 \%)$ & $43(3.3 \%)$ & $8(66.7 \%)$ \\
\hline $\begin{array}{c}\text { History of drug } \\
\text { intake }\end{array}$ & No & $15(50 \%)$ & $13(86.7 \%)$ & $2(13.3 \%)$ \\
\cline { 2 - 5 } History of infection & Yes & $15(50 \%)$ & $3(20 \%)$ & $12(80 \%)$ \\
\cline { 2 - 5 } & No & $12(40 \%)$ & $11(91.7 \%)$ & $1(8.3 \%)$ \\
\hline \multirow{2}{*}{$\begin{array}{c}\text { CMV } \\
\text { Infection }\end{array}$} & Yes & $18(60 \%)$ & $3(16.7 \%)$ & $15(83.3 \%)$ \\
\cline { 2 - 5 } & Pogative & $21(70 \%)$ & $18(85.8 \%)$ & $3(14.2 \%)$ \\
\hline
\end{tabular}




\begin{tabular}{|c|c|c|c|c|}
\hline \multirow{2}{*}{$\begin{array}{c}\text { Toxoplasma } \\
\text { Infection }\end{array}$} & Negative & $21(70 \%)$ & $18(85.8 \%)$ & $3(14.2 \%)$ \\
\cline { 2 - 5 } & Positive & $9(30 \%)$ & $3(33.3 \%)$ & $6(66.7 \%)$ \\
\hline HSV & Negative & $26(86.7 \%)$ & $19(73 \%)$ & $7(27 \%)$ \\
\cline { 2 - 5 } Infection & Positive & $4(13.3 \%)$ & $1(25 \%)$ & $3(75 \%)$ \\
\hline Rubella & Negative & $25(83.3 \%)$ & $22(88 \%)$ & $3(12 \%)$ \\
\cline { 2 - 5 } Infection & Positive & $5(16.7 \%)$ & $1(20 \%)$ & $4(80 \%)$ \\
\hline \multirow{2}{*}{ IgM antibody } & Negative & $16(53.3 \%)$ & $14(87.5 \%)$ & $2(12.5 \%)$ \\
\cline { 2 - 5 } & Positive & $14(46.7 \%)$ & $2(14.3 \%)$ & $12(85.7 \%)$ \\
\hline \multirow{2}{*}{ IgG antibody } & Negative & $16(53.3 \%)$ & $14(87.5 \%)$ & $2(12.5 \%)$ \\
\cline { 2 - 5 } & Positive & $14(46.7 \%)$ & $2(14.3 \%)$ & $12(85.7 \%)$ \\
\hline
\end{tabular}

The distribution of maternal karyotype according to lifestyle characteristics were showed in Table 3. According to the clinical condition $37.5 \%$ subjects were showed normal maternal karyotype and $62.5 \%$ subjects showed abnormal maternal karyotype. In the case of history of illness 3.3\% were showed normal maternal karyotype and $66.7 \%$ were showed abnormal maternal karyotype. History of drug intake was observed and $20 \%$ were normal maternal karyotype and $80 \%$ had abnormal maternal karyotype. History of infection showed $16.7 \%$ were normal maternal karyotype and $83.3 \%$ had abnormal maternal karyotype. Subjects with infections such as CMV, Toxoplasma, HSV, Rubella and subjects with antibodies $\operatorname{IgM}$ and $\operatorname{IgG}$ were positively correlated to $\mathrm{BOH}$ and the report showed increased incidence of abnormal karyotype. These findings were demonstrated that there is a positive correlation between duration of married life, infection, history of illness and history of drug intake with chances of bad obstetric history.

\section{Discussion:-}

Maternal age and previous miscarriage rates increases the risk of subsequent miscarriages. Women experience an age dependent increase in various adverse reproductive events such as infertility, pregnancy complications (De et al., 2002). In the present study also observed that increased maternal age is a risk factor for increased karyotypic abnormalities.

According to Seshiah, (2009) state's that more than 4 years of duration of married life is a serious risk factor of miscarriage. It causes parental chromosomal abnormality it will lead to miscarriage or any foetal chromosomal abnormalities. In the case of duration of married life, the paternal karyotype abnormality increases with increased duration.

Clinford et al., (1997) on his studies in couple with BOH showed that higher the number of previous pregnancy losses and number of gestation period influence in $\mathrm{BOH}$. In the present study also observed that the number of gestation increases the abnormal maternal karyotype also increases.

Devi et al., (2008) reported that primary infection with TORCH complex in pregnant women can lead to adverse outcome, which is initially in apparent or asymptomatic and thus difficult to diagnose on clinical. In the current study, if the mother were infected with Toxoplasma, Rubella, Cytomegalous virus, Herpes simplex virus and other infection were also showed a higher abnormal maternal karyotype.

Mishra et al., (2007) showed that anticardiolipin ( $\operatorname{IgG}$ and $\operatorname{IgM}$ ) antibody test was positive in $28.3 \%$ of patient with recurrent miscarriage. The present study also showed that the presence of $\operatorname{IgG}$ and $\operatorname{IgM}$ antibodies cause abnormal maternal karyotype.

\section{Conclusion:-}

The present study was carried out in 30 subjects with bad obstetric history. The main objectives of this study were to detect the various cytogenetic and immunologic factors that associated with bad obstetric history and to detect the chromosome abnormalities in patients with bad obstetric history, to avoid the risk of future pregnancies.

The couples who had reported for the bad obstetric history showed a higher percentage of abnormal karyotype. The abnormal karyotype was found higher in those couples with an increased age and increased duration of married life. Abnormal maternal karyotype was found higher in increased number of gestations, increased number of abortions 
and increased number of MTPs. The increased incidence of BOH was found and in those who had history of infection, illness, drug intake and antibodies such as IgM and IgG.

The couples karyotype analysis with respect to demographic factors such as maternal age, paternal age and duration of married life. The maternal karyotype analysis with respect to clinical and lifestyle factors such as number of gestations, number of abortions, number of MTPs, history of infections, history of illness, history of drug intake, IgM and IgG antibodies etc. showed increased level of abnormal karyotype. The study demonstrated that a positive correlation with karyotypic abnormality and various risk factors associated with $\mathrm{BOH}$. So the causes of $\mathrm{BOH}$ can be thoroughly assessed through cytogenetic and immunologic analysis.

\section{Reference:-}

1. Kumari, N., Morris, N., and Dutta, R., (2011): Is screening of TORCH worthwhile in women with bad obstetric history? An observation from eastern Nepal. Journal of Health, Population, and Nutrition; 29(1): 77 80 .

2. Meka. A., et al., (2006): Recurrent Spontaneous Abortions: An Overview of Genetic and Non-Genetic Backgrounds .Int J Hum Genet: 6(2):109-117.

3. Nickerson, J.P., Richner, B., Santy, K., Lequin, M.H., Poretti, A., Filippi, C.G., et al., (2012): Neuroimaging of pediatric intracranial infection, Part 2: TORCH, viral, fungal, and parasitic infections. J. Neuroimaging, 22(2): e42 e51.

4. Simpson, J.L., and Elias, S., (2003): Genetics in Obstetrics and Gynecology. Philadelphia, USA: Saunders: 101-132.

5. Sutandar, M., et al., (2007): Hypothyroidism in Pregnancy. Obstet Gynaecol Can. 29(4):354 356.

6. Nadia Mudher Al-Hilli., and Hadi Mohammad Al-Mosawi., (2014): The Prevalence of Anticardiolipin Antibodies in women with Bad Obstetric History. ISSN: 2319-7706 Volume 3 Number 2. pp. 547-553

7. Boonruang, S., Buppasiri, P., (2005): Rubella antibodies in normal pregnant women at Srinagarind hospital, KhonKaen Thailand. J Med Assoc Thai; 88:455-9.

8. JiHyae Lim., (2013): Cell-Free Fetal DNA and Cell-FreeTotal DNA Levels in Spontaneous Abortion with Fetal Chromosomal Aneuploidy; 8(2): 56-87.

9. Andersen, A.M.N., Wohlfahrt, J., Christens, P., Olsen, J., and Melbye, M., (2000): Maternal age and fetal loss: population based register linkage study; 1708-171.

10. Al-Hilli, N.M. et al., (2014): Int.J.Curr. Microbiol.App.Sci, 547-553.

11. Ambroise-Thomas, P., and Petersen., (2000): Congenital toxoplasmosis. Scientificbackground, clinical managment and control. Paris. Springer; Pp 344-6.

12. Paul ME. Disorders of reproduction. 1994. Prim Care, 21(2): 367-86.

13. Seshiah, V., Sahay, B.K., Das, A.K., Shah, S., Banerjee, S., Rao, P.V., Ammini, A., Balaji, V., Gupta, S., Divakar, H., Misra, S., and Thanawala, U., (2009): Gestational diabetes mellitus-Indian guidelines. J Indian Med Assoc; 107: 799-802, 804-806.

14. Clifford, K., Flanagan, A.M., and Regan, L., (1997): Endometrial CD56+ naturalkiller cells in women with recurrent miscarriage: a histomorphometric study. Hum.Reprod, 14: 2727-2730.

15. De Bruin, J.P., Dorland, M., Spek, E.R., Posthuma, G., van Haaften, M., Looman, C.W., (2002): Ultrastructure of the resting ovarian follicle pool in healthy young women. BiolReprod; 66:1151-1160.

16. Mishra, N.M., Sapna Gupta., Gupta, M.K., (2007): Significance of antiphospholipid antibodies in patients with bad obstetric history .Indian Journal of Medical Science: Volume:61 Issue:12 Page:663- 664.

17. Devi, K.S., Devi, Y.G., Singh, N.S., Singh, A.M., Singh, I.D., (2008): Seroprevalence of TORCH in women with still birth in RIMS hospital. Journal of Medical Society; 22: 24. 